\title{
Phytopathogenic fungi in forest nurseries of Middle Siberia
}

\author{
Marina A Sheller ${ }^{(1-2)}$, \\ Elena A Shilkina ${ }^{(1)}$, \\ Aleksey A Ibe ${ }^{(1)}$, \\ Tatyana Y Razdorozhnaya ${ }^{(1)}$, \\ Tatyana V Sukhikh ${ }^{(1)}$
}

\begin{abstract}
The paper presents the results of phytopathogenic fungi determination in bare-root forest nurseries of Middle Siberia. Genetic analysis of pathogenic microflora of Pinus sylvestris L., Pinus sibirica Du Tour and Picea obovata Ledeb. seedlings allowed identification of 17 genera of micromycetes: Phoma Sacc., Lophodermium Chevall., Sclerophoma Höhn. (teleomorph Sydowia Bres.), Cladosporium Link, Alternaria Nees, Typhula (Pers.) Fr. etc. Most frequently detected fungi represented genera Phoma (23.7\%) and Lophodermium (23.6\%). Pinus sylvestris L. seedlings harboured the highest diversity of fungal taxa. Seven genera of microscopic fungi (Phoma sp., Didymella sp., Alternaria sp., Cladosporium sp., Lophodermium sp., Gremmenia sp., Sclerophoma sp.) were detected in all studied forest zones: taiga, forest-steppe and Southern-Siberian mountain. The obtained results demonstrate the usefulness of DNA analysis for the identification of phytopathogenic fungi in forest nurseries of Middle Siberia with several implications for increasing the efficacy of forest management.
\end{abstract}

Keywords: Forestry, Forest Nurseries, Phytopathogens, Conifers, DNA analysis, ITS Region, Phytopathological Monitoring

of microbial cenoses in forest nursery soils, associated with an adverse environmental situation is one of the causes of fungal epiphytotics in the region (Shilkina 2004). The study of the microbial community and the combination of a wide range of environmental factors that determine its stability and variability deserves attention concerning possible prediction of the spread of certain groups of microorganisms, in particular plant pathogenic fungi.

It is rather difficult to define the border between fungal infections because they usually begin with similar symptoms and their visual inspection is often unreliable (Stenström et al. 2014, Shestibratov et al. 2018). In this case the molecular genetic analysis is one of the most effective methods of early diagnostics and taxonomical determination of pathogens in forest nurseries. It allows detecting pathogen DNA with high accuracy and at an early stage of the disease development (Kernaghan et al. 2003, Menkis 2005, Baranov et al. 2010,
(1) Department of Monitoring of Forest Genetic Recourses, Branch of the Russian Centre of Forest Health - Centre of Forest Health of Krasnoyarsk krai, Akademgorodok 50a/2, 660036 Krasnoyarsk (Russia); (2) Reshetnev Siberian State University of Science and Technology, Krasnoyarskii rabochii prospect 31, 660037 Krasnoyarsk (Russia)

@ Marina A Sheller (maralexsheller@mail.ru)

Received: May 15, 2020 - Accepted: Sep 03, 2020

Citation: Sheller MA, Shilkina EA, Ibe AA, Razdorozhnaya TY, Sukhikh TV (2020). Phytopathogenic fungi in forest nurseries of Middle Siberia. iForest 13: 507-512. - doi: 10.3832/ifor3507-013 [online 2020-11-05]

Communicated by: Federica Brunoni
Okorski et al. 2019). The goal of our study was to identify phytopathogenic fungi on Pinus sylvestris L., Pinus sibirica Du Tour and Picea obovata Ledeb. seedlings in 29 bareroot forest nurseries of Middle Siberia by sequencing the internal transcribed spacer of the fungal ribosomal DNA (ITS rDNA).

\section{Material and methods}

The microflora of 1410 Scots pine (Pinus sylvestris L.), 600 Siberian stone pine (Pinus sibirica Du Tour) and 600 Siberian spruce (Picea obovata Ledeb.) diseased seedlings from 29 forest nurseries of Middle Siberia was studied over a period of 6 years. The forest nurseries are located in three forest zones: taiga, forest-steppe, Southern-Siberian mountain (Consortium Kodeks 2020 - Tab. 1, Fig. 1). Before sampling, the forest nurseries were examined and then 30 seedlings with disease symptoms (yellowing, browning, damping off, etc.) were drawn from the entire area in each age group (Innovations in Russia 2013). The plants without signs of damage were used as control samples. Additionally, 435 control samples were analyzed.

The laboratory analyses generally followed the study by Menkis et al. (2006). In brief, DNA from the damaged plant tissues (needles) was extracted using the Cetyl Trimethyl Ammonium Bromide (CTAB) method (Doyle \& Doyle 1990). The universal primers ITS 1 and ITS4 were used to amplify the ITS1-5.8S/ITS2 regions between the $18 \mathrm{~S}$ and $28 \mathrm{~S}$ nuclear rDNA (White et al. 1990). PCR was performed using GenPak ${ }^{\circledR}$ PCR Core Kit (Laboratory Isogen Ltd., Russia); $20 \mu \mathrm{l}$ of the reaction mix were prepared including $2.5 \mu \mathrm{l}$ of each primer (20 $\mu M)$ and $5 \mu$ l of DNA template. The amplifi- 
Tab. 1 - Twenty-nine forest nurseries in Middle Siberia where diseased seedlings of Pinus sylvestris L., Pinus sibirica Du Tour and Picea obovata Ledeb. were investigated using direct sequencing method. Forest zones: (T) Taiga; (Fs) Forest-steppe; (SSm) SouthernSiberian mountain.

\begin{tabular}{|c|c|c|c|}
\hline No & Forest nursery & $\begin{array}{l}\text { Forest } \\
\text { zone }\end{array}$ & Fungal taxa \\
\hline 1 & Abanskiy & T & Lophodermium seditiosum, Phoma sp., Gremmenia sp., Typhula intermedia, Sclerophoma sp. \\
\hline 2 & Bolsheuluyskiy & T & Alternaria tenuissima, Alternaria alternata, Alternaria sp., Phoma sp., Herpotrichia sp. \\
\hline 3 & Dolgomostovskiy & T & Cladosporium sp., Phoma sp., Didymella macrostoma \\
\hline 4 & Kemskiy & T & Typhula intermedia, Lophodermium seditiosum, Alternaria sp. \\
\hline 5 & Maklakovskiy & T & Gremmenia infestans, Phoma sp., Lophodermium seditiosum \\
\hline 6 & Pirovskiy & $\mathrm{T}$ & Alternaria sp. \\
\hline 7 & Reshotinskiy & $\mathrm{T}$ & $\begin{array}{l}\text { Cladosporium sp., Lophodermium seditiosum, Gremmenia infestans, Phoma sp., Rhizoctonia sp., } \\
\text { Typhula sp. }\end{array}$ \\
\hline 8 & Taseevskiy & $\mathrm{T}$ & $\begin{array}{l}\text { Cladosporium sp., Lophodermium seditiosum, Lophodermium sp., Phoma sp., Rhizoctonia solani, } \\
\text { Sclerophoma sp. }\end{array}$ \\
\hline 9 & Tinskiy & $\mathrm{T}$ & Phoma sp., Typhula sp. \\
\hline 10 & Tyukhtetskiy & $\mathrm{T}$ & Herpotrichia juniperi \\
\hline 11 & Bogradskiy & Fs & Phoma sp. \\
\hline 12 & Dzerzhinskiy & Fs & Sclerophoma sp. \\
\hline 13 & Ilanskiy & Fs & Lophodermium seditiosum, Sclerotinia sp. \\
\hline 14 & Kemchugskiy & Fs & $\begin{array}{l}\text { Botrytis sp., Cladosporium sp., Coleosporium sp., Didymella macrostoma, Lophodermium seditiosum, } \\
\text { Lophodermium sp., Phoma sp. }\end{array}$ \\
\hline 15 & Maganskiy & Fs & Lophodermium seditiosum, Typhula sp. \\
\hline 16 & Mininskiy & Fs & Didymella pomorum, Phoma sp. \\
\hline 17 & Sukhobuzimskiy & Fs & Alternaria sp., Phoma sp. \\
\hline 18 & Tayezhnyy & Fs & Lophodermium seditiosum, Phoma sp., Typhula sp. \\
\hline 19 & Talovskiy & Fs & $\begin{array}{l}\text { Alternaria sp., Cladosporium sp., Lophodermium seditiosum, Gremmenia sp., Phoma sp., } \\
\text { Gremmeniella abietina, Sclerophoma sp., Septorioides pini-thunbergii }\end{array}$ \\
\hline 20 & Trudnovskiy & Fs & Botrytis sp., Cladosporium sp., Herpotrichia sp., Phoma sp., Sclerophoma sp. \\
\hline 21 & Tuimskiy & Fs & Phoma sp. \\
\hline 22 & Uzhurskiy & Fs & Didymella glomerata, Lophodermium seditiosum, Lophodermium sp., Phoma sp. \\
\hline 23 & Uyarskiy & Fs & Phoma sp. \\
\hline 24 & Verkhnemanskiy & $\mathrm{SSm}$ & Lophodermium seditiosum, Lophodermium sp. \\
\hline 25 & Goryachegorskiy & SSm & $\begin{array}{l}\text { Alternaria sp., Cladosporium sp., Didymella macrostoma, Epicoccum sp., Phoma sp., Rhizoctonia } \\
\text { solani }\end{array}$ \\
\hline 26 & Ermakovskiy & $\mathrm{SSm}$ & $\begin{array}{l}\text { Alternaria alternata, Alternaria tenuissima, Cladosporium sp., Lophodermium pinastri, Lophodermium } \\
\text { seditiosum, Gremmenia sp., Phoma sp., Sclerophoma sp. }\end{array}$ \\
\hline 27 & Kazyrskiy & SSm & Phoma sp. \\
\hline 28 & Verkhnetashtypskiy & SSm & Phoma sp., Rhizoctonia solani \\
\hline 29 & Shalinskiy & SSm & $\begin{array}{l}\text { Cladosporium herbarum, Cladosporium sp., Lophodermium seditiosum, Phoma sp., Ramularia sp., } \\
\text { Sclerotinia nivalis }\end{array}$ \\
\hline
\end{tabular}

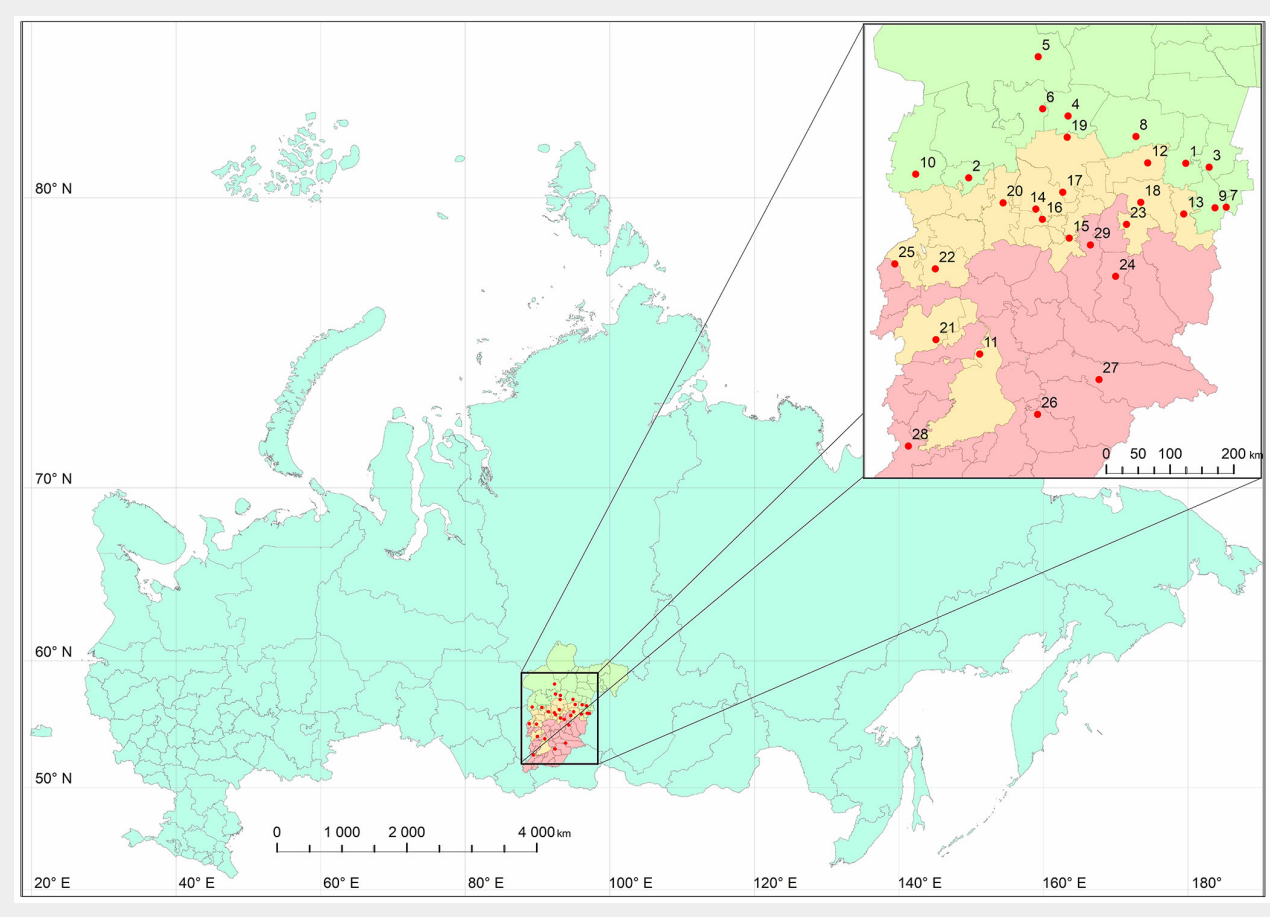

Fig. 1 - Map of Russia showing the locations of the investigated forest nurseries (numbered 1-29 as in Tab. 1) from which seedlings were collected. Forest nurseries are indicated by red dots. Taiga, forest-steppe and Southern-Siberian mountain zones are indicated by green, orange and pink, respectively. 
cation cycle consisted of an initial denaturation step at $94{ }^{\circ} \mathrm{C}$ for $1 \mathrm{~min}$, followed by 35 cycles of $94{ }^{\circ} \mathrm{C}$ for $15 \mathrm{sec}, 60{ }^{\circ} \mathrm{C}$ for 20 $\mathrm{sec}$, and $72{ }^{\circ} \mathrm{C}$ for $26 \mathrm{sec}$, and a final extension at $72{ }^{\circ} \mathrm{C}$ for $10 \mathrm{~min}$. The PCR products were electrophoresed in a $2 \%$ agarose gel in Tris-borate-EDTA (TBE) (1x) buffer, stained with ethidium bromide and visualized under UV light. The PCR products were then excised and purified using the BioSilica Kit (BioSilica Ltd., Russia) following the manufacturer's instructions. Sequencing reactions were performed using the BigDye ${ }^{\circledR}$ Terminator v3.1 Cycle Sequencing Kit (Applied Biosystems, Foster City, (A, USA) according to the manufacturer's instructions. The DNA sequence analysis was performed on an ABI PRISM $310^{\oplus}$ genetic analyzer (Applied Biosystems, Foster City, CA, USA). For taxonomic identification sequences were submitted to the $\mathrm{NCBI}$ Genbank database (NCBI 2020). The criteria used for identification were: sequence coverage $>80 \%$, identity to species level 98 $100 \%$, identity to genus level $94-97 \%$. Sequences not matching those criteria or lacking taxonomic names in the reference sequences were considered unidentified and therefore were not taken into analysis. The taxonomy of identified fungi was updated in accordance with the international database Index Fungorum (2020).

\section{Results and discussion}

Amplification of fungal ITS rDNA from 2610 diseased seedlings was successful for 2341 (89.7\%) samples. Each of the PCR reactions produced one to three amplicons. Direct sequencing of all amplicons resulted in 2710 sequences. Among them, 1596 (58.9\%) sequences were identified and taken into analysis. DNA analysis of 435 control samples resulted in 159 sequences. However, $72(45.3 \%)$ of them were of low quality and were discarded from the analysis. Eightyseven control samples contained genetic material of saprotrophic (Aspergillus sp., Penicillium sp., Rhizopus sp.) and conditionally pathogenic fungi (Phoma sp., Sclerophoma sp., Cladosporium sp.).

The representatives of 17 genera of pathogenic and conditionally pathogenic fungi were identified in forest nurseries of Middle Siberia: Phoma Sacc. and Didymella Sacc., Lophodermium Chevall., Sclerophoma Höhn. (teleomorph Sydowia Bres.), Cladosporium Link, Alternaria Nees, Typhula (Pers.) Fr., Herpotrichia Fuckel., Gremmenia Korf., Rhizoctonia DC., Sclerotinia Fuckel, Botrytis P. Micheli ex Pers., Coleosporium Lév, Epicoccum Link, Gremmeniella M. Morelet (Scleroderris [Fr.] Bonord.), Septorioides Quaedvl., Verkley \& Crous, Ramularia Sacc. Interestingly, 7 genera of these micromycetes were found in all studied forest zones, but most of them were present in nurseries located in foreststeppe zones (Tab. 2). Apart from this, several genera of mold fungi were also determined in infected seedlings: Aspergillus P. Micheli, Penicillium Link and Rhizopus Ehr-

Tab. 2 - Phytopathogens observed on Pinus sylvesrtis L., Pinus sibirica Du Tour and Picea obovata Ledeb. seedlings in different forest zones of Middle Siberia.

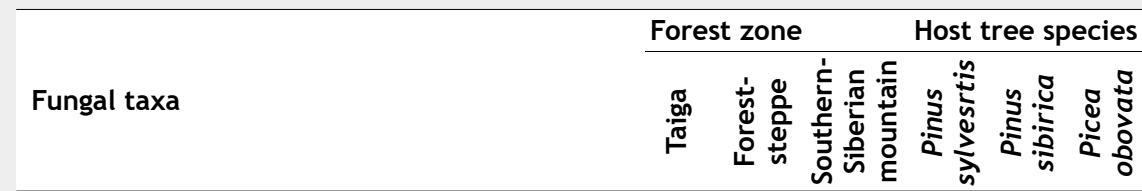

Alternaria sp. (A. alternata [Fr.] Keissl.)

Alternaria sp. (A. tenuissima [Kunze] Wiltshire)

Alternaria sp.

Botrytis sp.

Cladosporium sp.

Cladosporium sp. (C. herbarum [Pers.] Link)

Didymella (D. glomerata [Corda] Q. Chen \& L.

Cai)

Didymella (D. macrostoma [Mont.] Q. Chen \& L.

Cai)

Didymella (D. pomorum [Thüm.] Q. Chen \& L.

Cai)

Epicoccum sp.

Gremmenia sp.

Gremmenia sp. (G. infestans [P. Karst.] Crous =

Phacidium infestans P. Karst.)

Gremmeniella sp. (G. abietina [Lagerb.] M.

Morelet $=$ Scleroderris lagerbergii Gremmen)

Herpotrichia sp.

Herpotrichia juniperi (Sacc.) Petr.

Lophodermium sp. (L. seditiosum Minter, Staley \& Millar)

Lophodermium sp. (L. pinastri [Schrad.]

Chevall.)

Phoma sp.

Sclerophoma sp. (teleomorph - Sydowia Bres.)

Septorioides sp. (S. pini-thunbergii [S. Kaneko]

Quaedvl., Verkley \& Crous)

Typhula sp.

Typhula sp. (T. intermedia Appel \& Laubert)

Sclerotinia sp.

Sclerotinia sp. (S. nivalis I. Saito)

Ramularia sp.

Rhizoctonia sp.

Rhizoctonia sp. (R. solani J.G. Kühn)

Coleosporium sp.

\begin{tabular}{|c|c|c|c|c|c|}
\hline+ & - & + & + & - & + \\
\hline+ & - & + & - & - & - \\
\hline- & + & + & - & + & - \\
\hline- & + & - & + & - & - \\
\hline+ & + & + & + & + & - \\
\hline- & - & + & - & - & + \\
\hline- & + & - & + & - & - \\
\hline+ & + & + & + & - & + \\
\hline- & + & - & - & + & - \\
\hline- & - & + & - & - & + \\
\hline- & + & + & - & + & + \\
\hline+ & - & - & + & - & - \\
\hline- & + & - & + & - & - \\
\hline+ & + & - & - & + & - \\
\hline+ & - & - & - & - & + \\
\hline+ & + & + & + & + & - \\
\hline- & - & + & - & + & - \\
\hline+ & + & + & + & + & + \\
\hline+ & + & + & + & + & + \\
\hline- & + & - & - & + & - \\
\hline- & + & - & + & - & - \\
\hline+ & - & - & - & - & - \\
\hline- & + & - & + & - & - \\
\hline- & - & + & - & - & + \\
\hline- & - & + & - & + & - \\
\hline+ & - & - & + & - & - \\
\hline- & - & + & - & + & - \\
\hline- & + & - & - & - & - \\
\hline
\end{tabular}

enb. Such molds are likely part of the seedlings natural microflora or are contaminants from soil that accumulate on seedling shoots while lifting (Sutherland et al. 1991). In each of the nurseries pathogenic microflora was represented by 1-8 genera of microscopic fungi (Tab. 1). Ascomycetes were the most common fungi identified in the forest nurseries of Middle Siberia.

Scots pine seedlings harboured the highest diversity of fungal taxa (Fig. 2). Mostly these are the fungi of genera Lophodermium and Phoma, as well as Typhula, Cladosporium, Alternaria, Sclerophoma, Rhizoctonia, Gremmenia, Didymella, Sclerotinia, Botrytis, Coleosporium, Gremmeniella. Eleven genera of micromycetes were found on diseased seedlings of Siberian stone pine. Among them the most dominant are Sclerophoma, Cladosporium, Herpotrichia and Phoma. The studied micro- flora of Siberian spruce seedlings exhibited the lowest diversity of fungal taxa, with a predominance of Phoma sp., Sclerophoma sp. and Alternaria sp. Consequently, six genera of micromycetes were detected on diseased seedlings of all studied host tree species: Alternaria, Cladosporium, Didymella, Gremmenia, Phoma and Sclerophoma.

The analysis showed that fungi belonging to the genus Phoma (23.7\%) were the most common phytopathogens found on diseased seedlings in forest nurseries of Middle Siberia (Fig. 3). They were detected on Scots pine, Siberian stone pine and Siberian spruce seedlings in 22 nurseries. Phoma species are ubiquitous soil inhabitants. The fungi invade seedlings from soil, usually through the lower needles, then infection spreads up the seedling crown, affecting needles until the seedling is defoliated (James 2012). Phoma spp. occur through- 


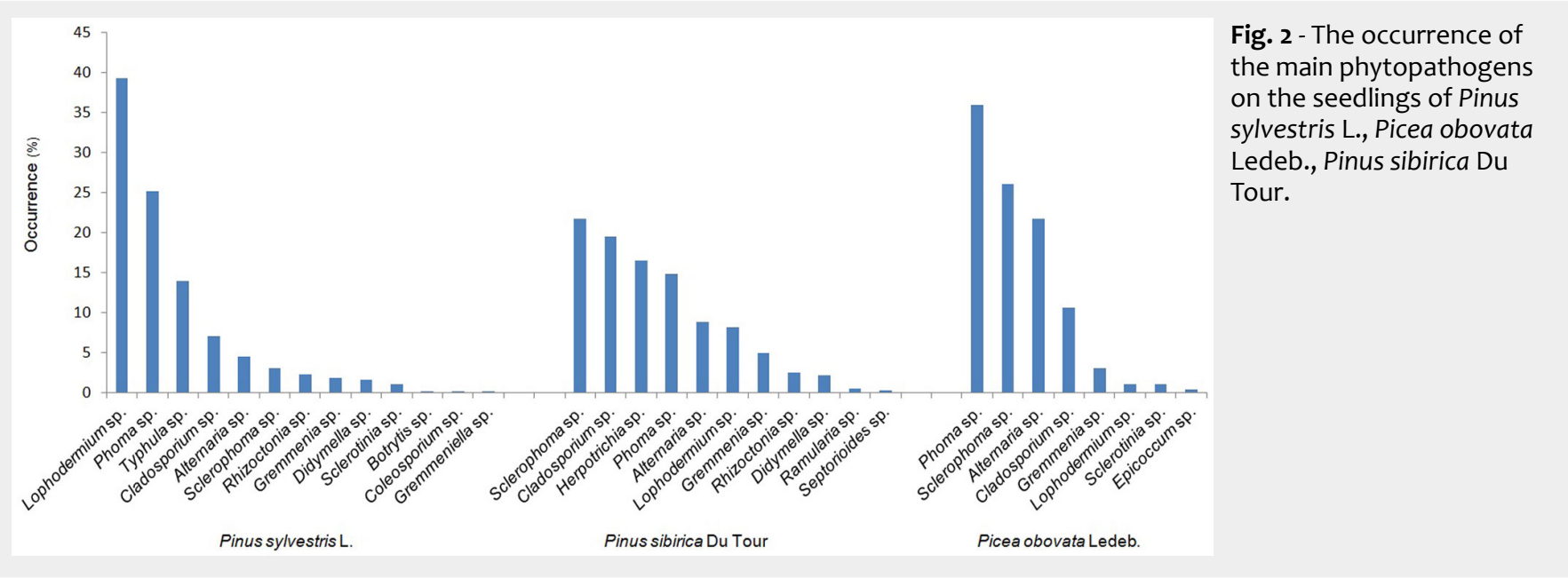

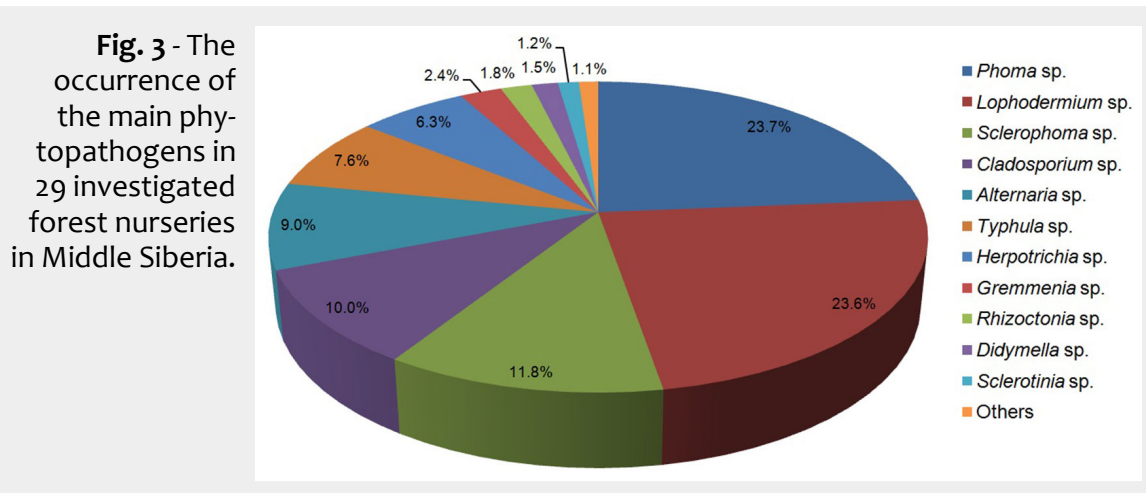

out the world and can be of significant eco- tices also could lead to natural accumulanomic importance (Aveskamp et al. 2008, tion of the infection in forest nurseries. It Seredich 2016). In forest nurseries of Mid- should be noted that the identification of dle Siberia Phoma species have not been previously diagnosed and therefore scarce information is available on the pathogenic fungi of this genus in the region.

The increase of the environmental extremes due to climate change may have caused Phoma fungi to become active in forest nurseries of Middle Siberia. As in many cases of poor health, environmental factors play a key role in the probability of infection and transmission of the pathogen (Lilja et al. 2010). Intensive cultivation prac-
Phoma fungi in forest nurseries of Middle Siberia has become possible mainly due to the implementation of molecular genetic diagnostics into phytopathological monitoring of forest nurseries. Hence, the study of Phoma species biology, ecology and pathogenic activities in the microflora of coniferous seedlings is of great scientific and practical interest. Besides, a number of identified species of the genus Didymella (1.5\%), such as D. macrostoma, D. glomerata, D. pomorum, were previously classified to the genus Phoma. It also indicates the need for accurate study of the taxonomy of Phoma species (Shilkina et al. 2018).

The second most frequently occurred phytopathogens found in 14 forest nurseries were Lophodermium fungi (23.6\%). Lophodermium is a well-known fungal genus which occurs in pine needles (OrtizGarcía et al. 2003, Millberg 2015). In the present study two species of this genus were identified in needles of Scots pine and Siberian stone pine seedlings, namely $L$. seditiosum and $L$. pinastri. Of these two species, only L. seditiosum is considered to be pathogenic, causing Lophodermium needle cast disease (Stenström \& Ihrmark 2005, Lilja et al. 2010). L. pinastri is reported to be non-pathogenic fungus that lives endophytically within pine needles (Minter \& Millar 1980). The obtained results are in agreement with another study (Grodnitskaya \& Kuznetsova 2012), which showed that $L$. seditiosum and $L$. pinastri were widely spread on pine seedlings in forest nurseries of Middle and South Siberia.

Cladosporium (C. Herbarum - $10 \%$ ) and Alternaria (A. alternata, A. Tenuissima - $9 \%$ ) were also among the most common pathogens found in 9 and 7 nurseries, respectively. They were detected on all of the

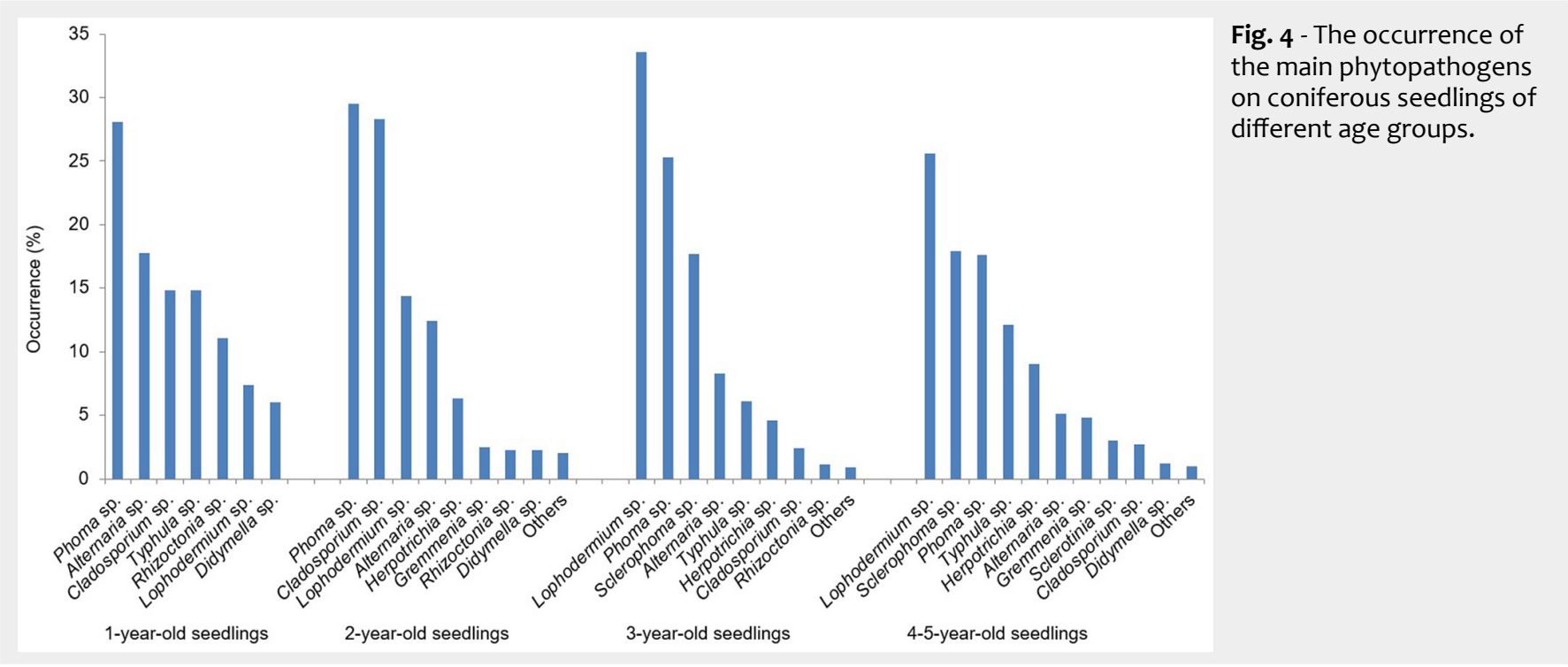


studied host tree species and in all forest zones. In addition, Cladosporium fungi were present with low abundance in the epiphytic microflora of healthy plants. Alternaria and Cladosporium are facultative parasites mainly associated with plants weakened by unfavorable climatic conditions (Yarmolovich et al. 2016). In forest nurseries they usually cause post-emergence damping-off (Procházková \& Vlastislav 1991). It is worth to point out that in Middle Siberia the most common casual agents of post-emergence damping-off are Fusarium fungi (Yakimenko \& Grodnitskaya 2000, Shilkina 2004). In the present study they might not have been detected by DNA analysis due to the poor quality of several obtained sequences.

Sclerophoma (11.8\%), Herpotrichia (6.3\%) and Gremmenia (2.4\%) were detected in 6, 3 and 5 forest nurseries, respectively. Most of the nurseries were located in taiga and forest-steppe zones. Fungi of the genera Sclerophoma and Gremmenia were found on Scots pine, Siberian stone pine and Siberian spruce seedlings, while Herpotrichia sp. was detected only on Siberian stone pine and Siberian spruce seedlings. Sclerophoma sp. (teleomorph, Sydowia Bres.) was frequently determined on damaged plants and ranked third on the occurrence. In some cases the stems of seedlings infected by Sclerophoma had S-shaped bending which is one of the symptoms of the disease. Sclerophoma is reported to be a weak pathogen which occasionally causes serious damage of trees under stress (Kraj et al. 2009). Snow blight of conifers seedlings in surveyed nurseries was caused by Gremmenia infestans and Herpotrichia juniperi. In forest nurseries of Siberia it is a generally known disease which is successfully diagnosed by macro- and microscopic methods and there are specific recommendations for its prevention and control (Shilkina et al. 2018).

The typical genera of snow mold, Typhula (7.6\%) and Sclerotinia (1.2\%), were found on Scots pine and Siberian spruce seedlings in 6 and 2 nurseries, respectively. Most species of Typhula and Sclerotinia are low-temperature tolerant and are widely distributed in cold regions in the Northern Hemisphere (Hoshino et al. 2009, Matsumoto 2009). In Middle Siberia snow mold caused by Typhula sp., unlike Sclerotinia sp., is poorly studied on conifers and its identification has become easier only with the use of DNA analysis (Shilkina et al. 2018). Current research showed that the disease is widespread in forest nurseries located in taiga and forest-steppe zones. Consequently, the study of its agents is relevant for the development of reasonable methods of prevention and protection.

Among the rarely diagnosed phytopathogens of seedlings were Rhizoctonia fungi (1.8\%). Rhizoctonia solani was identified on Scots pine and Siberian stone pine seedlings in 4 forest nurseries located in taiga and Southern-Siberian mountain zones.
Rhizoctonia blight, caused by species of Rhizoctonia, occurs on many pine species and can lead to severe damages of seedlings in bare-root nurseries, e.g., dampingoff and rot of roots, stems, needles, and terminal buds (Starkey \& Enebak 2012). In forest nurseries of Middle Siberia the fungi of the genus Rhizoctonia were only detected in soil, but their harmfulness for seedlings was not observed (Gromovykh et al. 2005). Single cases of occurrence were detected for Botrytis sp., Gremmeniella sp., Coleosporium sp. (Scots pine), Septorioides sp. (Siberian stone pine), Epicccocum sp. (Siberian spruce). Given the low frequency of occurrence these pathogens do not pose a strong threat and therefore do not have current economic significance in forest nurseries of Middle Siberia. The analysis of the presence of the main phytopathogens on seedlings of different age groups has revealed that the most predominant pathogens of one- and two-year-old plants are Phoma sp., Alternaria sp., Cladosporium sp. and Typhula sp.; three- four- and fiveyear-old seedlings were mostly affected by Lophodermium sp., Phoma sp., Sclerophoma sp. and Typhula sp. (Fig. 4).

In this study, the spectrum of phytopathogenic fungi on seedlings of Scots pine, Siberian stone pine and Siberian spruce was identified using DNA sequencing. In each of the studied forest nurseries of Middle Siberia the pathogenic microflora are represented by 1-8 genera of micromycetes. The most common phytopathogens detected on 1-5-year old coniferous seedlings were Phoma sp., Alternaria sp., Cladosporium sp., Lophodermium sp., Sclerophoma sp. and Typhula sp. The rest pathogens were less common and their emergence was likely associated with unsuitable cultivation practices.

\section{Conclusions}

The study showed that phytopathological monitoring of forest nurseries by molecular genetic analysis is a useful approach for identification of fungal infections in planting material. The identification of pathogens can be helpful in reducing the fungal diseases in forest nurseries of Middle Siberia. It should be recommended to carry out preventive measures against detected phytopathogens with fungicides allowed to be used in forestry. However, the application of chemicals for diseases control is quite uncertain in forest nursery production in Russia. Most of the available fungicides are registered only for agricultural crops. New, effective and eco-friendly fungicides are not introduced yet, which is a serious problem for afforestation. Therefore, considerable research for environmentally safe and easily biodegradable biofungicides should be carried out.

\section{List of abbreviations}

- DNA - deoxyribonucleic acid;

- PCR - polymerase chain reaction

\section{Acknowledgements}

M.A.S. and E.A.S. wrote the manuscript. M.A.S., A.A.I., T.Y.R. and T.V.S. carried out the investigation.

The research was carried out within the State Assignment (theme "Fundamental principles of forest protection from entomo- and phyto- pests in Siberia" no. FEFE 2020-0014) supported by the Ministry of Education and Science of the Russian Federation and the State Coordination Program for the Development of Biotechnology in the Russian Federation for 20112020.

We would also like to thank three anonymous reviewers for their useful comments and suggestions.

\section{References}

Aveskamp MM, De Gruyter J, Crous PW (2008). Biology and recent developments in the systematics of Phoma, a complex genus of major quarantine significance. Fungal Diversity 31: 118. [online] URL: http://library.wur.nl/WebQue ry/wurpubs/372744

Baranov OY, Oszako T, Nowakowska JA, Panteleev SV (2010). Genetic identification of fungi colonizing seedlings of the Scots pine (Pinus sylvestris L.) in the forest nursery in Korenevka (Belarus). Folia Forestalia Polonica 52 (1): 61-64. [online] URL: http://depot.ceon.pl/handle/1234 $56789 / 5550$

Bespalova V, Gedio V, Polyanskaya O, Shaitarova O, Tereshchenko S (2019). Sustainable forest management is one of Russia's economic problems. In: Proceedings of the "Forest of Russia: Policy, Industry, Science and Education”. St. Petersburg (Russia), 22-24 May 2019. IOP Conference Series - Earth and Environmental Science 316 (2019): 012086. - doi: 10.1088/1755-1315/316/ $1 / 012086$

Consortium Kodeks (2020). Approval of the list of areas of forest growth and forest areas of the Russian Federation. Order no. 367 (18 Aug 2014), Ministry of Natural Resources and the Environment, Russian Federation, Web site. [in Russian] [online] URL: http://docs.cntd.ru/doc ument/420224339

Desprez-Loustau ML, Marçais B, Nageleisen LM, Piou D, Vannini A (2006). Interactive effects of drought and pathogens in forest trees. Annals of Forest Science 63: 597-612. - doi: 10.1051/for est:2006040

Doyle JJ, Doyle JL (1990). Isolation of plant DNA from fresh tissue. Focus 12: 13-15.

Grodnitskaya ID, Kuznetsova GV (2012). Diseases of Pinus sylvestris L. and Pinus sibirica Du Tour in provenance trial and forest nurseries of Krasnoyarsk krai and Khakassia. Conifers of the Boreal Area 27 (3-4): 55-60. [in Russian with English abstract]

Gromovykh TI, Litovka Y, Andreeva ON (2005). Biomonitoring of conifer seedling diseases in forest tree nurseries of the middle Siberia. Siberian State Technological University, Krasnoyarsk, Russia, pp. 264 [in Russian]

Hoshino T, Xiao N, Tkachenko OB (2009). Cold adaptation in phytopathogenic fungi causing snow molds. Mycoscience 50 (1): 26-38. - doi: 10.1007/S10267-008-0452-2

Index Fungorum (2020). The Index Fungorum 
database. Web site. [online] URL: http://www. indexfungorum.org/

Innovations in Russia (2013). Program and methodology of work under item 59 of the Action plan "The State Coordination Program for the Development of Biotechnology in the Russian Federation for 2011-2020". Order no. 1247-p (18 Jul 2013), Government of the Russian Federation, Moscow, Russia, Web site. [online] URL: http://innovation.gov.ru/node/14244

James RL (2012). Phoma blight. In: "Forest Nursery Pests" (Kasten Dumroese R ed). Agriculture Handbook no. 680, USDA Forest Service, Washington, DC, USA, pp. 54-55. [online] URL: http:// books.google.com/books?id=0tP28ObeoZ8C

Kernaghan G, Sigler L, Khasa D (2003). Mycorrhizal and root endophytic fungi of containerized Picea glauca seedlings assessed by rDNA sequence analysis. Microbial Ecology 45: 128136. - doi: 10.1007/s00248-002-1024-1

Keča N (2016). Review of the most important pathogens in Serbian forest nurseries. Reforesta 1: 164-177. - doi: 10.21750/REFOR.1.09.9

Kraj W, Kowalski T, Zarek M (2009). Differentiation and genetic structure of Sclerophoma pythiophila (Corda) V. Hoehn. strains associated with various damage and disease symptoms on Pinus sylvestris L. Acta Agrobotanica 62 (1): 57-65. - doi: 10.5586/aa.2009.007

Lilja A, Poteri M, Petäistö R-L, Rikala R, Kurkela T, Kasanen $R$ (2010). Fungal diseases in forest nurseries in Finland. Silva Fennica 44 (3): 525545. - doi: 10.14214/sf.147

Matsumoto N (2009). Snow molds: a group of fungi that prevail under snow. Minireview. Microbes and Environments 24 (1): 14-20. - doi: 10.1264/jsme2.ME09101

Menkis A (2005). Root associated fungi of conifer seedlings and their role in afforestation of agricultural land. Doctoral thesis, Swedish University of Agricultural Sciences, Uppsala, Sweden, pp. 31. [online] URL: http://pub.epsilon.slu. se/955/

Menkis A, Vasiliauskas R, Taylor AFS, Stenström $E$, Stenlid J, Finlay R (2006). Fungi in decayed roots of conifer seedlings in forest nurseries, afforested clear-cuts and abandoned farmland. Plant Pathology 55: 117-129. - doi: 10.1111/j.13653059.2005.01295.x

Millberg H (2015). Foliar fungi of Scots pine (Pinus sylvestris). Ph.D. thesis, Swedish University of Agricultural Sciences, Uppsala, Sweden, pp. 50. [online] URL: http://pub.epsilon.slu.se/126 831
Minter DW, Millar CS (1980). Ecology and biology of three Lophodermium species on secondary needles of Pinus sylvestris. European Journal of Forest Pathology 10 (2-3): 169-181. - doi: 10.1111/j.1439-0329.1980.tbooo23.x

NCBI (2020). NCBI Genbank database. National Center for Biotechnology Information, US National Library of Medicine, Bethesda, MD, USA, Web site. [online] URL: http://https.ncbi.nlm. nih.gov/

Ndobe EN (2012). Fungi associated with roots of healthy-looking Scots pines and Norway spruce seedlings grown in nine Swedish forest nurseries. Ph.D. thesis, Swedish University of Agricultural Sciences, Uppsala, Sweden, pp. 41. [online] URL: http://stud.epsilon.slu.se/4246/

Okorski A, Pszczólkowska A, Gorzkowska A, Okorska S, Gluszek P (2019). Fungi associated with conifer seedlings grown in forest nurseries under different systems. Environmental Engineering and Management Journal 18 (7): 1509-1517. doi: 10.30638/eemj.2019.141

Ortiz-García S, Gernandt DS, Stone JK, Johnston PR, Chapela IH, Salas-Lizana R, Alvarez-Buylla ER (2003). Phylogenetics of Lophodermium from pine. Mycologia 95 (5): 846-59. - doi: 10.1080/15572536.2004.11833044

Procházková Z, Vlastislav J (1991). Diseases in Czechoslovak forest nurseries. In: Proceedings of the $1^{\text {st }}$ Meeting of IUFRO Working Party S2:07-09 "Diseases and Insects in Forest Nurseries" (Sutherland JR, Glover SG eds). Information Report BC-X-331, Pacific Forestry Centre, Canadian Forestry Service, Victoria, BC, Canada, pp. 37-49.

Seredich MO (2016). Cultural and morphological characteristics of fungus Phoma sp. 1 - Phoma blight causing agents in coniferous tree seedlings. Proceedings of BSTU 1: 98-101. [online] URL: http://elib.belstu.by/handle/123456789/20 825

Shestibratov KA, Baranov Yu O, Subbotina NM, Lebedev VG, Panteleev SV, Krutovsky KV, Padutov VE (2018). Early detection and identification of the main fungal pathogens for resistance evaluation of new genotypes of forest trees. Forests 9: 732. - doi: 10.3390/f9120732

Shilkina EA (2004). Ecological and biological justification of the use of fungicides in the protection of Pinus sylvestris L. seedlings from phytopathogenic micromycetes. Ph.D. thesis, Sukachev Institute of Forest SB RAS, Krasnoyarsk, Russia, pp. 50. [in Russian]

Shilkina EA, Sheller MA, Razdorozhnaya Yu T, Ibe
AA (2018). DNA diagnostic results of forest nurseries phytopathogenic fungi of Krasnoyarsk Krai and the Republic of Khakassia. The Siberian Journal of Forest Science 2: 15-27. [in Russian with English abstract] [online] URL: http://www.cabdirect.org/cabdirect/abstract/2 0183179009

Starkey T, Enebak SA (2012). Rhizoctonia blight of southern pines. In: "Forest Nursery Pests" (Kasten Dumroese R ed). Agriculture Handbook no. 680, USDA Forest Service, Washington, DC, USA, pp. 63-65. [online] URL: http:// www.researchgate.net/publication/265713887 Stenström E, Ihrmark K (2005). Identification of Lophodermium seditiosum and L. pinastri in Swedish forest nurseries using species-specific PCR primers from the ribosomal ITS region. Forest Pathology 35 (3): 163-172. - doi: 10.1111/j. 1439-0329.2005.00398.x

Stenström E, Ndobe NE, Jonsson M, Stenlid J, Menkis A (2014). Root-associated fungi of healthy-looking Pinus sylvestris and Picea abies seedlings in Swedish forest nurseries. Scandinavian Journal of Forest Research 29 (1): 12-21. doi: $10.1080 / 02827581.2013 .844850$

Sutherland JR, Greifenhagen S, Juzwik J, Davis C (1991). Diseases and insects in forest nurseries in Canada. In: Proceedings of the $1^{\text {st }}$ Meeting of IUFRO Working Party S2:07-09 "Diseases and Insects in Forest Nurseries" (Sutherland JR, Glover SG eds). Information Report BC-X-331, Pacific Forestry Centre, Canadian Forest Service, Victoria, BC, Canada, pp. 25-32.

White TJ, Bruns T, Lee S, Taylor J (1990). Amplification and direct sequencing of fungal ribosomal RNA genes for phylogenetics. In: "PCR Protocols: A Guide to Methods and Applications" (Innis MA, Gelfand DH, Sninsky JJ, White TJ eds). Academic Press, San Diego, CA, USA, pp. 315-322.

Yakimenko EE, Grodnitskaya ID (2000). Effect of Trichoderma fungi on soil micromycetes that cause infectious conifer seedling lodging in Siberian tree nurseries. Microbiology 69 (6): 726-729. - doi: 10.1023/A:1026670627943

Yarmolovich VA, Baranov YO, Panteleev SV, Dishuk NG, Azovskaya NO (2016). Recommendation for the protection of planting material in forest nurseries from the most common diseases. Proceedings of BSTU 1: 102-104. [online] URL: http://elib.belstu.by/handle/123456789/20 823 ?locale $=$ en 